\title{
Metachronous colorectal adenocarcinoma at colostomy site 14 years after primary resection
}

\author{
Philip Donal McEntee, Paul H McCormick, David Edward Kearney
}

Colorectal Surgery, St James's Hospital, Dublin, Ireland

\section{Correspondence to} Mr David Edward Kearney; dkearnage@gmail.com

Accepted 5 March 2020

\section{DESCRIPTION}

A 65 -year-old woman heavy smoker presented to the emergency department with a productive cough and malaise on a background history of Chronic Obstructive Pulmonary Disease, poorly controlled type II diabetes mellitus, and malnutrition. 14 years prior to admission she underwent an abdominoperineal excision for a T3 N1 adenocarcinoma of the lower rectum, followed adjuvant chemotherapy. 11 years prior to admission a solitary metastasis was identified in segment 7 of her liver. She underwent a wedge resection of this followed by adjuvant chemotherapy. Subsequent surveillance imaging showed no further metastatic disease. She was admitted medically for treatment of a bilateral bronchopneumonia. During her admission her colostomy was examined on the ward and an asymptomatic $3 \mathrm{~cm}$ raised friable discoid mass was identified on the mucosal surface (see figures 1 and 2). She underwent a colonoscopy to her caecum where biopsies of this discoid lesion were taken. No other colonic abnormalities were identified. Histology from the biopsies demonstrated a moderately differentiated adenocarcinoma, colorectal type. A staging CT thorax, abdomen and pelvis showed no evidence of metastatic disease. Due to her significant comorbidities and malnutrition a peristomal excision of this tumour was recommended after discussion at the colorectal cancer multidisciplinary team meeting. Her end colostomy was freed circumferentially down to fascia. The fascial opening was widened to permit further mobilisation of her descending colon and $20 \mathrm{~cm}$ of colon with adjacent mesentery was resected. After fascial approximation a new end colostomy was created. Histological evaluation of the resection demonstrated a moderately differentiated adenocarcinoma, $32 \mathrm{~mm}$ in diameter, with

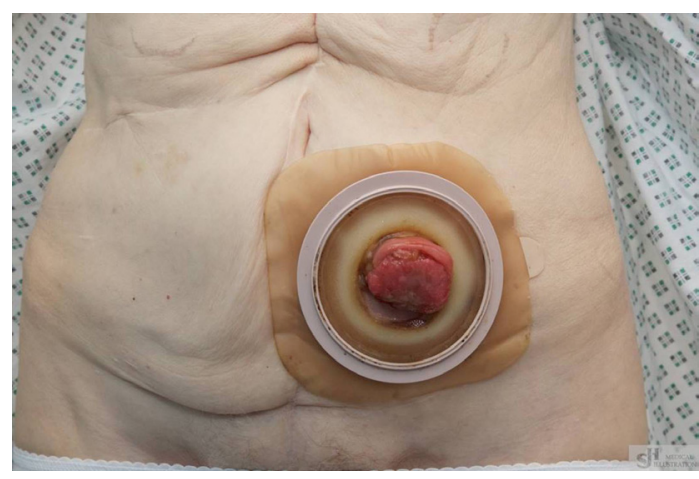

Figure 1 Preoperative image demonstrating a $3 \mathrm{~cm}$ raised discoid mass arising from the mucosal surface of the patient's end descending colostomy.

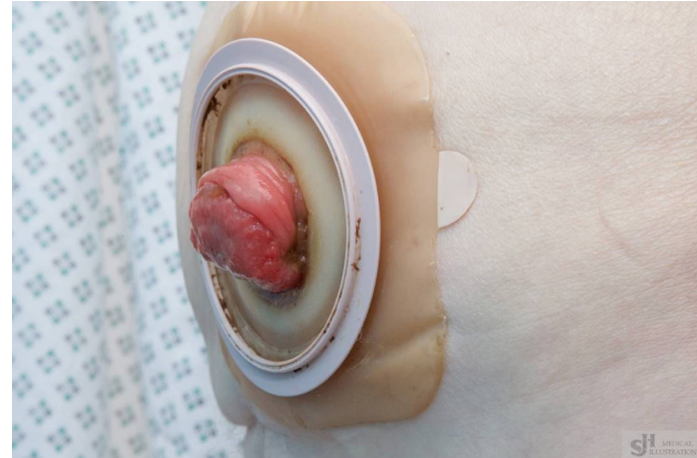

Figure 2 Side-view of discoid mass arising from end descending colostomy.

one of three nodes positive (T2N1a, R0 resection). There was no loss of mismatch repair genes to suggest Lynch syndrome. Adjuvant chemotherapy was recommended, however she only tolerated two cycles of this due to poor performance and ongoing weight loss. She is currently doing well and subsequent surveillance imaging over the past 18 months has no shown any evidence of metastatic disease.

Metachronous colorectal cancers develop in $1.5 \%-3 \%$ of patients, with the majority occurring within the first 3 years. ${ }^{1-3}$ However, cancers developing at colostomy sites are extremely rare with $<20$ cases reported in the literature. ${ }^{45}$ Due to the rarity of this entity, the exact aetiology has not been established but multiple hypotheses have been proposed such as physical mucosal damage from

\section{Patient's perspective}

I had stopped attending any formal stoma care a long time before this problem arose. I had noticed for a few weeks prior to my admission that my stoma had been a bit more active than normal but didn't really pay much attention to it. I didn't ever really look at the stoma itself because I never realised this sort of problem could happen. I suppose, in a way, I was lucky I got sick when I did because they might not have found the cancer until a lot later otherwise.

\section{Learning points}

- Metachronous tumours usually present within the first 3 years but may present much later.

- Always remember to examine the colostomy during a physical examination. 
persistent irritation, direct extension of disease or de novo metaplasia. ${ }^{67}$ Over half of the cases quoted in the literature involved tumours with infiltration into adjacent organs indicating that the tumours had been present for some time before detection. As outcomes from colorectal cancer continue to improve, the number of survivors living with stomas will increase. Although these tumours are rare it is important to educate patients to seek medical attention should they notice changes with their stomas, particularly as many of these tumour present outside of surveillance guidelines, as in our case.

Contributors PDMCE, PHMCC and DEK all contributed equally to the data collection, writing, editing and approval of the final version of the manuscript. DEK submitted the manuscript on behalf of all of the authors.

Funding The authors have not declared a specific grant for this research from any funding agency in the public, commercial or not-for-profit sectors.

Competing interests None declared.

Patient consent for publication Obtained.

Provenance and peer review Not commissioned; externally peer reviewed.
ORCID iD

David Edward Kearney http://orcid.org/0000-0002-9111-8666

\section{REFERENCES}

1 Barillari P, Ramacciato G, Manetti G, et al. Surveillance of colorectal cancer: effectiveness of early detection of intraluminal recurrences on prognosis and survival of patients treated for cure. Dis Colon Rectum 1996;39:388.

2 Green RJ, Metlay JP, Propert K, et al. Surveillance for second primary colorectal cancer after adjuvant chemotherapy: an analysis of intergroup 0089. Ann Intern Med 2002;136:261.

3 Fuccio L, Rex D, Ponchon T, et al. New and recurrent colorectal cancers after resection: a systematic review and meta-analysis of endoscopic surveillance studies. Gastroenterology 2019;156:1309-23.

4 Maeda C, Hidaka E, Shimada M, et al. Transverse colon cancer occurring at a colostomy site 35 years after colostomy: a case report. World I Surg Oncol 2015;13:171.

5 Iwamoto M, Kawada K, Hida K, et al. Adenocarcinoma arising at a colostomy site with inguinal lymph node metastasis: report of a case. Jpn J Clin Oncol 2015;45:217-20.

6 Kuo Y-H, Chin C-C, Lee K-F. Metastasis at the colostomy site: a rare case report. Jpn J Clin Oncol 2012:42:753-6.

7 Chintamani, Singhal V, Bansal A, et al. Isolated colostomy site recurrence in rectal cancer-two cases with review of literature. World J Surg Oncol 2007:5:52.

Copyright 2020 BMJ Publishing Group. All rights reserved. For permission to reuse any of this content visit

https://www.bmj.com/company/products-services/rights-and-licensing/permissions/

BMJ Case Report Fellows may re-use this article for personal use and teaching without any further permission.

Become a Fellow of BMJ Case Reports today and you can:

- Submit as many cases as you like

- Enjoy fast sympathetic peer review and rapid publication of accepted articles

- Access all the published articles

Re-use any of the published material for personal use and teaching without further permission

Customer Service

If you have any further queries about your subscription, please contact our customer services team on +44 (0) 2071111105 or via email at support@bmj.com.

Visit casereports.bmj.com for more articles like this and to become a Fellow 